\title{
Intolerable 2
}

\author{
Derrick Quintero
}

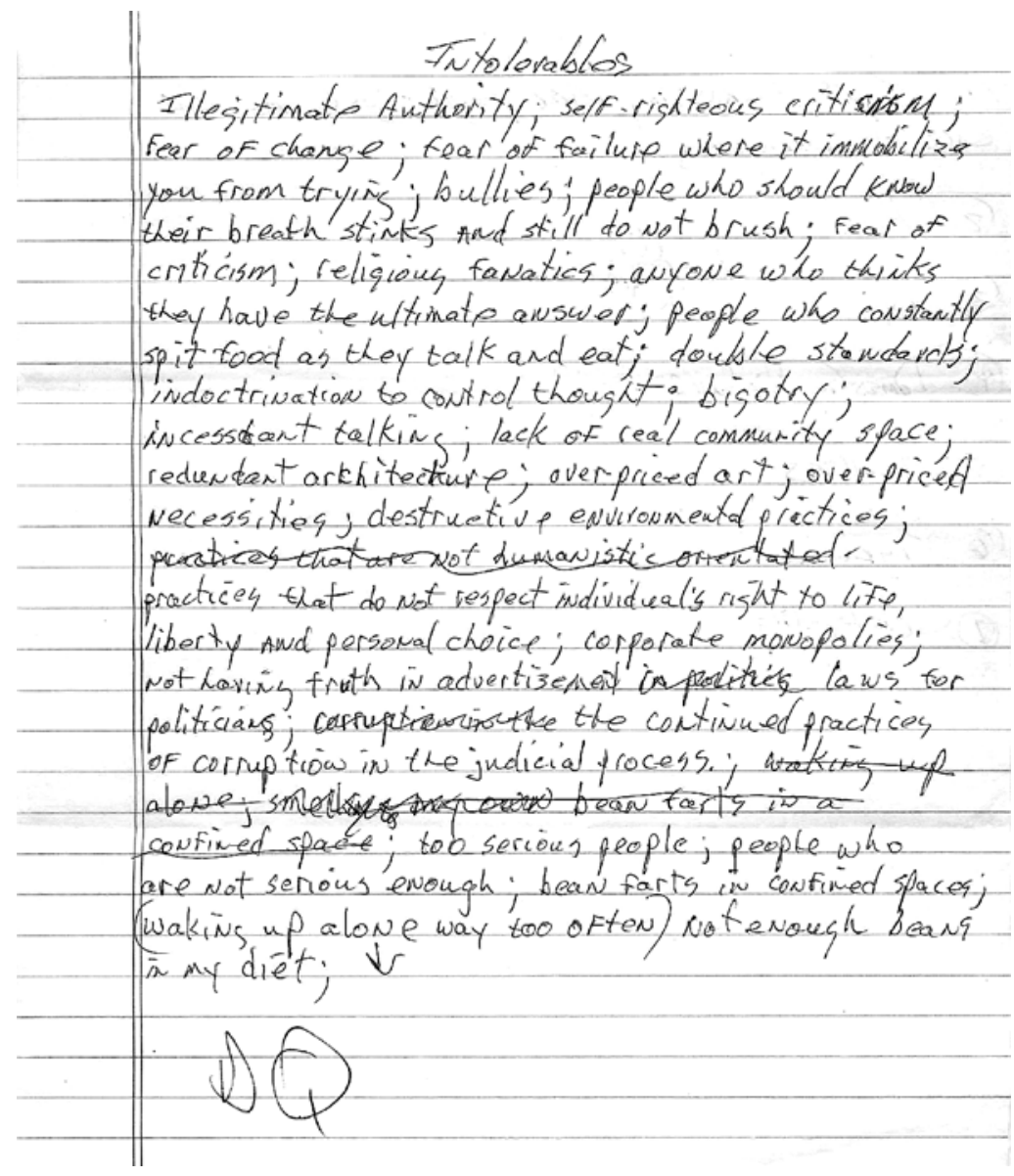

